\title{
PUBLIC RELATIONS IN RESTORATION WORK
}

\author{
Michael Smart*
}

The most obvious is not always the most important. This is very true with regard to restoration work in a disaster area. The most obvious needs will appear to be the restoration of buildings, roads, and communications, but these are in fact of secondary importance compared with restoring the confidence, nerves and hopes of the people involved. Any restoration work that is undertaken, especially in the first few days, should be of the kind that will help to boost morale and self-confidence. The people involved in such restoration work, should realize that many of the people they come in contact with will still be suffering from nervous strain and shock. Woricmen and overseers can contribute far more than the actual restoration of material things, for their attitude, sympathetic ear, and cheerful word means much to those who have gone through the disaster.

The people of Inangahua and Reefton were very appreciative of the long and at times dangerous hours that men from various Government and Civil Departments put in, especially during the first few days after the earthquake of the 24th May. The effect could in a way be likened to the arrival of fresh troops to help with the mopping up operations after a major battle. If the fresh troops seem unappreciative or insensitive to what the others have been through, then their presence will cause friction and tensions within the ranks, but the reverse is also true and in the main this is what happened after the initial "battle" of the 24 th May, 1968. Whether they like it or not, workmen, overseers, insurance assessors, government officials and M.P.s are involved in public relations work and should be conscious of this.

The above is not only important in so far as it effects the local resident, but most important in so far as it affects the relationship between such people and the local Civil Defence organization. But this will have received attention in another paper being contributed by the Civil Defence Controller.

In fact, a three man committee was set up by $\mathrm{Dr}$ Bruce Falconer, to effect good relations with local residents, especially in the area of insurance claims and rebuilding work. Mr Harold Yeatman (Ministry of Works), Mr John Lowery (Assessor) and Rev Michael Smart (representing local residents). were responsible for insuring good relations and progress especially within the major disaster area of Inangahua Camp and the surrounding district. As a member of this committee, I was well placed to see the great benefits of such a committee under these or similar circumstances. People tend to be suspicious whenever money is involved, and it must be realized that there will be doubts in the mind of some as to the likelihood of their receiving "a fair deal". Those of us on the Public Relations Committee are convinced that the presence of a disinterested party on such a committee helps to allay such suspicions and makes for easier relationships with people who are often distressed and unsure of their future. Having a local person, to represent the local people, is a sound move when setting up such a committee as was set up after the earthquake. 
I would at this point like to say how much I appreciated the sincerity and concerm of the two men with whom I worked on the Committee. Both Mr Yeatman and Mr Lowery showed a sensitivity and interest that made for easier relations with those affected by the disaster. There was no attempt to rush things through and people were given ample opportunity to understand and consider the insurance settlements and proposed building repairs. It should always be appreciated that people are on the whole rather ignorant about insurance matters and great care should therefore be taken to make them fully conversant with the whys and wherefores of insurance claims and settlements.

In this respect, considerable difficulty was experienced over the confusion of replacement value and indemnity value. The majority of poople thought that their insurance policy covered them for replacement value and naturally thought the insurance companies had "put it across" them when they discovered that they were only covered for indemnity value. It took a long time to get this fact over to people and caused no end of trouble in our settlement of claims. It would seem that people need to realize that they ought to consider reducing the amount of insurance on their buildings in accordance with the indemnity value of the same.

Though there were some difficulties experienced due to delays in payments, it should be placed on record that the various assessors representing the Earthquake and War Damage Commission, worked very hard and long hours both in the field and at night in their offices. Most of these men, working under the supervision of Mr Don Bird, were very good in their public relations, but the odd difficulty that did arise in certain cases shows the need for placing men in the field who are appreciative of the fact that they are not just dealing with buildings and contents.

It is most important that people have access to the details of the assessment, so that they can know how much they have been allowed for each particular item. (e.g. for their chimneys, their roofing iron etco). As mentioned in the previous paragraph, however, it would have to be made clear to the owner that what he is being assessed on is indemnity value and not replacement value, otherwise misunderstanding can arise when the actual repair accounts are received.

At the end of the period under the control of Civil Defence, Government set up a continuing committee to be responsible for the overall supervision of restoration work in all fields. This Coinmittee, under the chairmanship of $\mathrm{Mr} S$. Hamblett, would have found things easier if they had been given the chance to become familiar with operations and local conditions before they were asked to take over the reins. It is very difficult to come into an area and pick up the reins without some period of familiarization. In terms of public relations, I would think it desirable if such a continuing committee were given the opportunity to work within the framework of the local Civil Defence; then when the tine came for them to take over from the Civil Defence Controller, they would have been in on things almost from the word go. Perhaps Government could consider having men ready to take up such a role if and when a disaster occurs in their area.

If one accepts the premise that people matter more than things, then public relations becomes of prime importance in any restoration work. Should a disaster, such as the one experienced on the West Coast, this year of 1968, occur in an area of greater population density, then $I$ would think it necessary to have several men and women capabie of dealing with people's questions, fears and criticisms. After Civil Defence lifted the emergency, it would seem a wise move to have at hand 
a public relations office to which people might go in order to seek or air their problems. The staff of such an office could then, when necessary, refer such people to the respective men in charge of that area of restoration most related to the person's problem. Such would also protect the field workers from unnecessary delay in their work.

Again I would express appreciation of the sensitive way in which most people coming into the disaster area went about their restoration work. What has been learnt here on the West Coast should be of benefit to the whole country and make us nore prepared to deal with any future disasters. 


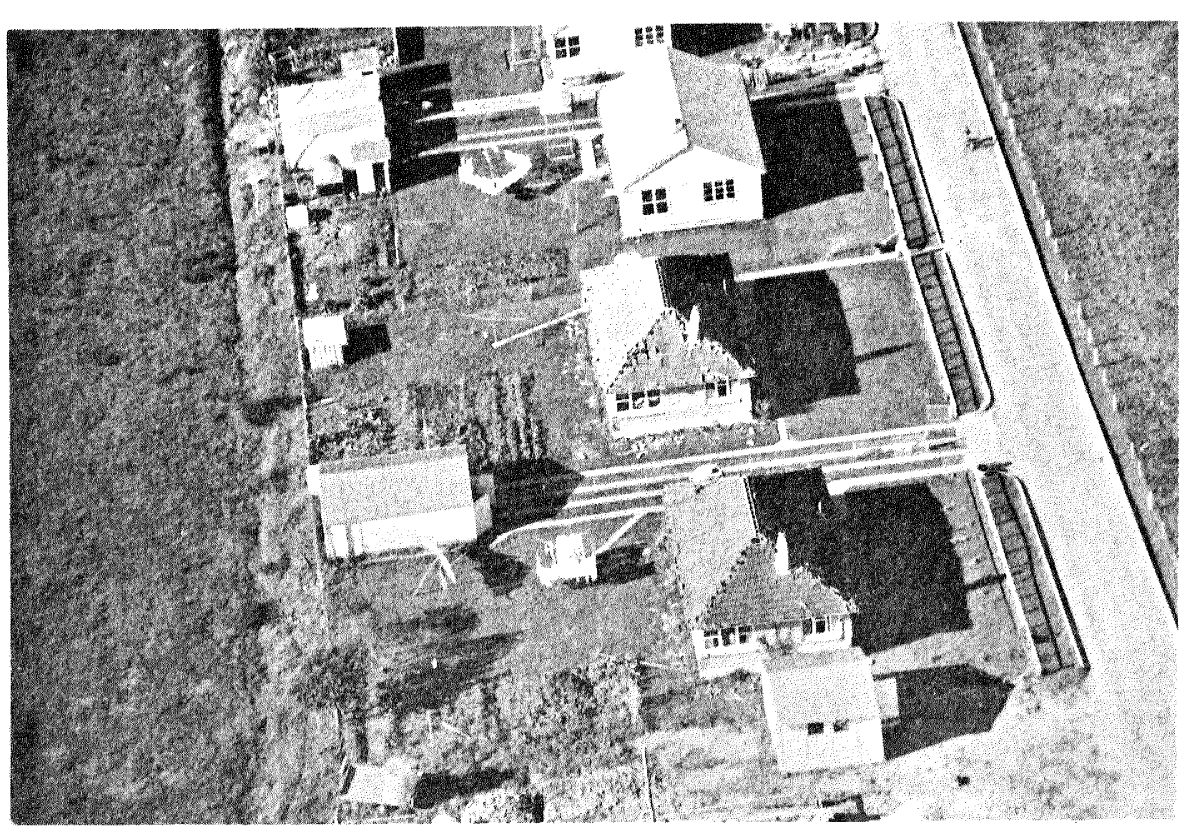

Fig. 9. Dwellings in Inangahua Camp, two with tiles \& veneer

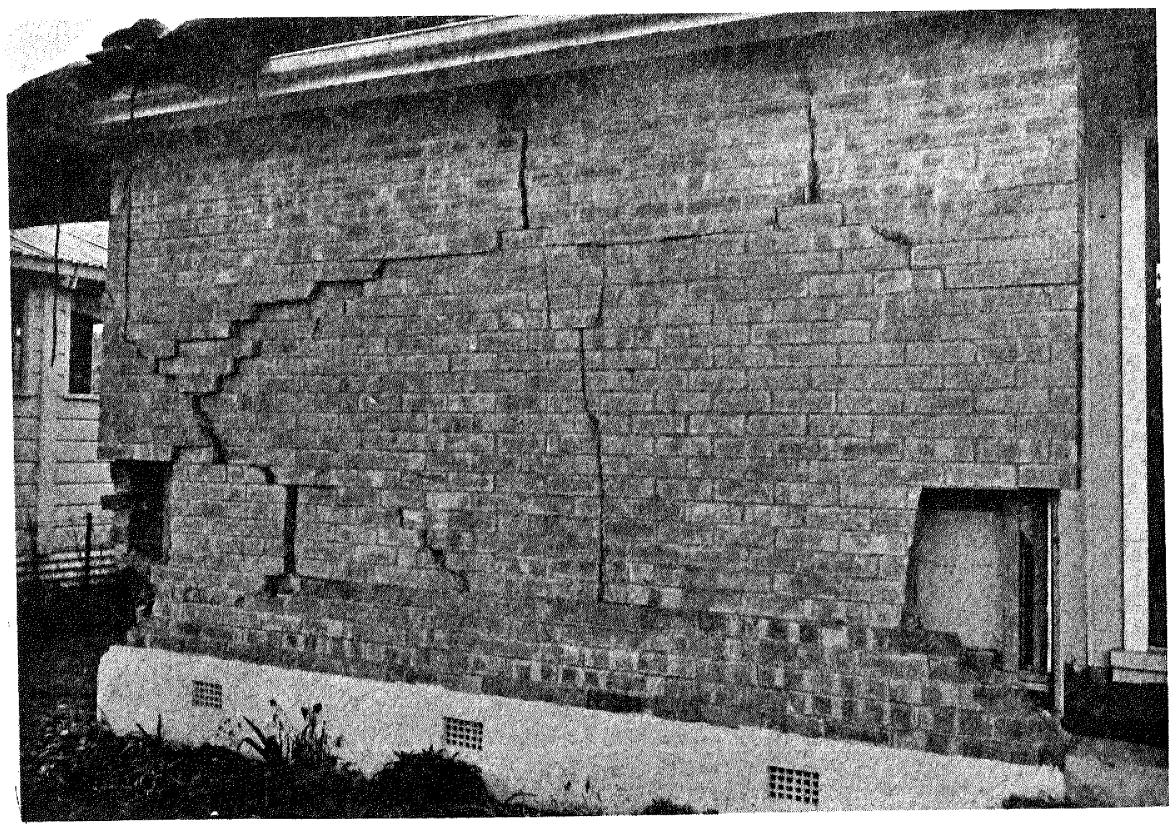

Fig. 10. Damaged 1st building of fig. 9. Tarpaulin on roof.

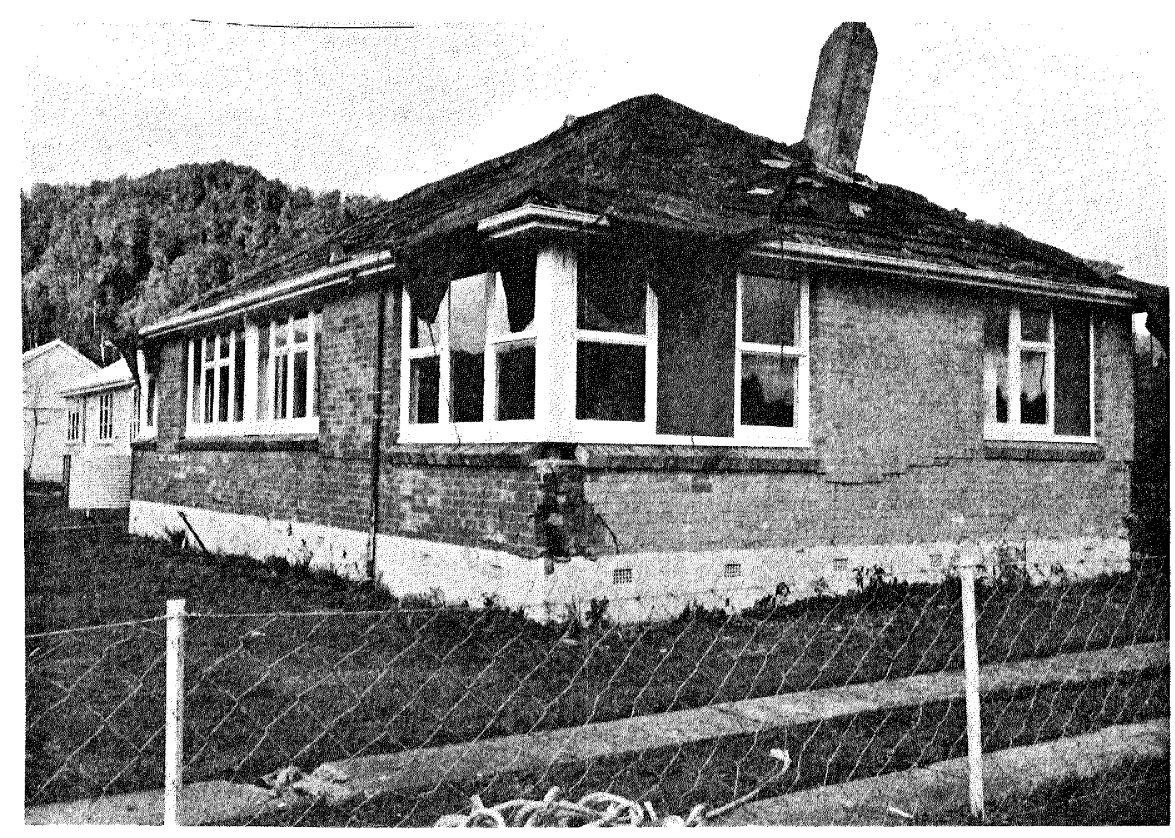

Fig. 11. Shattered brick veneer of dwelling of fig. 9

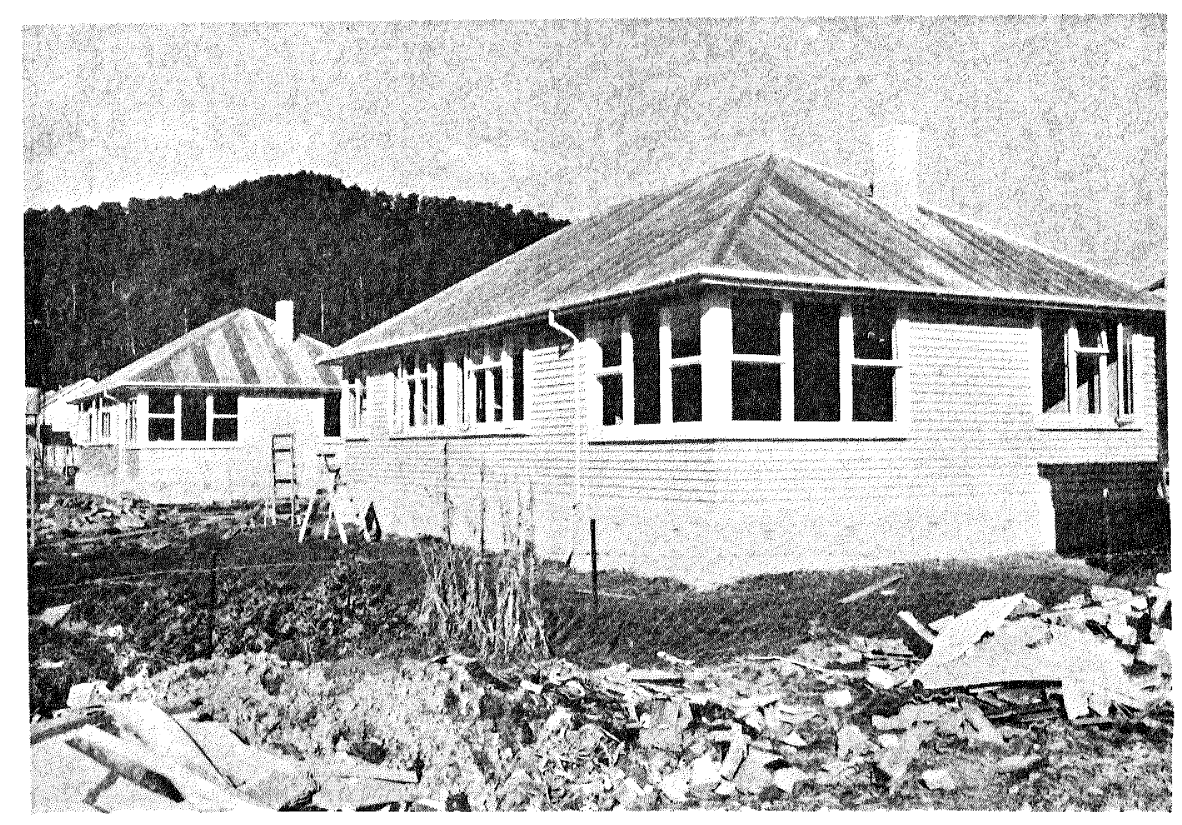

$\stackrel{d}{g}$ 


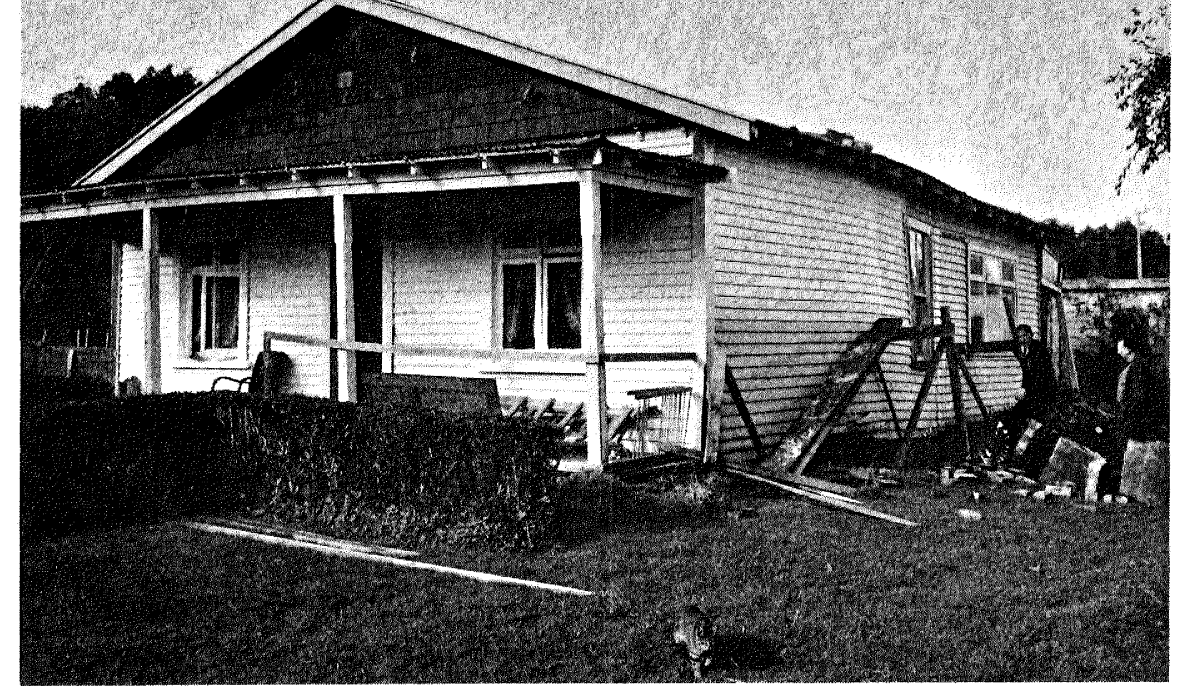

Fig. 13. Dwelling $2 \mathrm{~km}$ south of "Junction", moved off piles

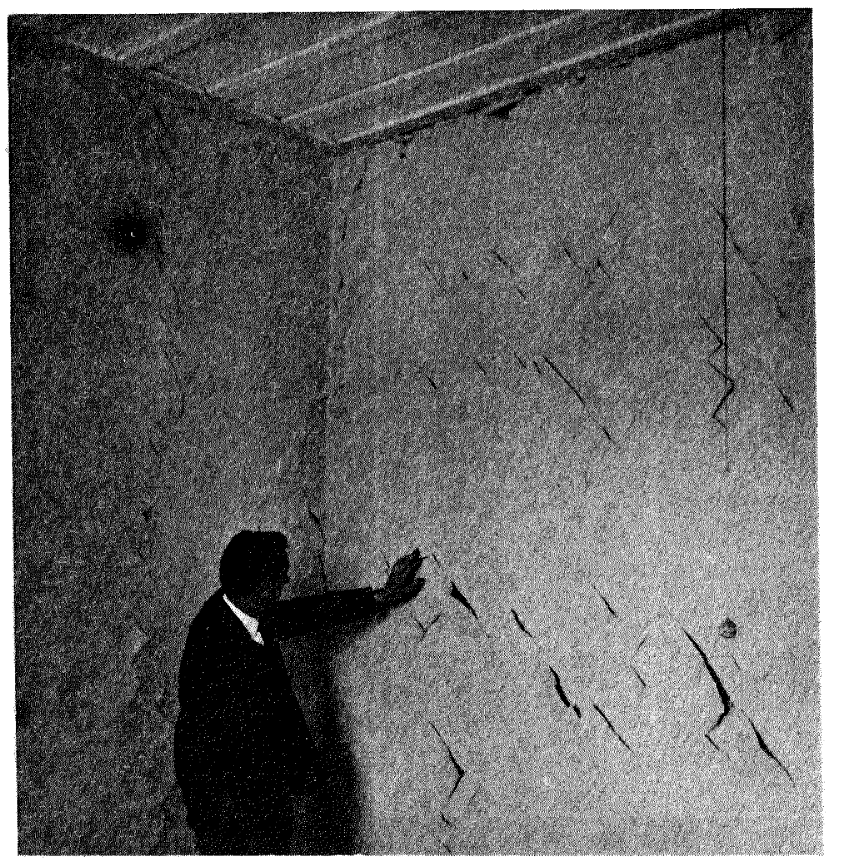

$\overrightarrow{\mathrm{p}}$ Fig. 14. Torn wall paper shows reversals of movement

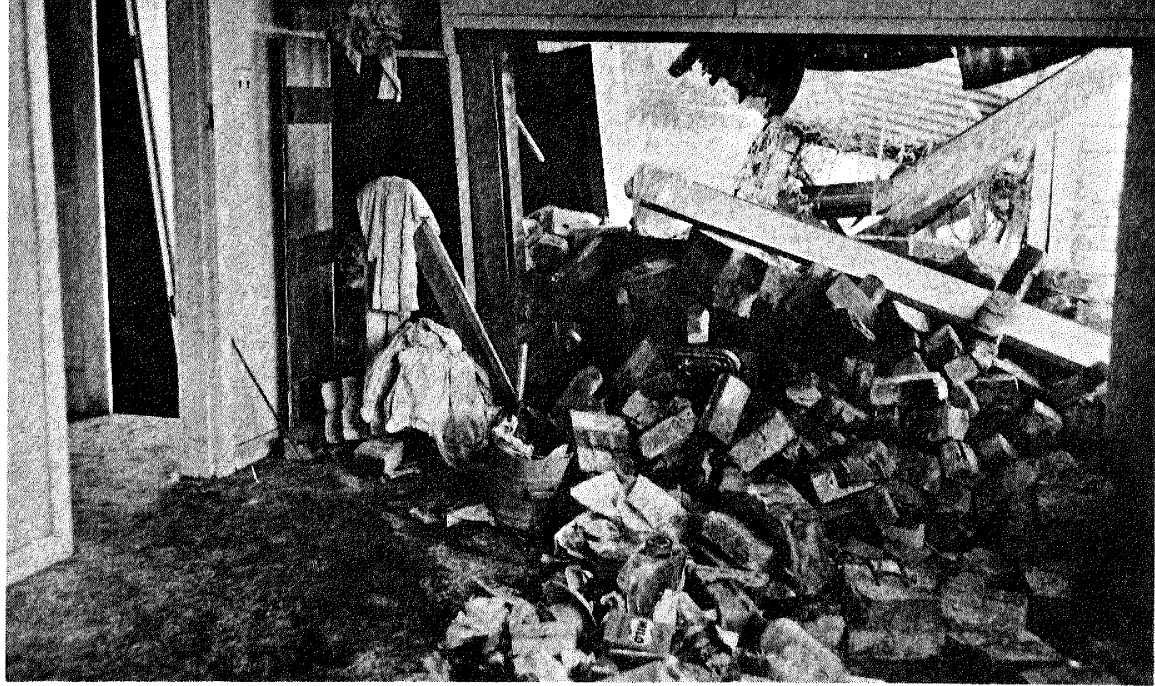

Fig. 15. Scene, kitchen, collapsed chimney and cooking stove

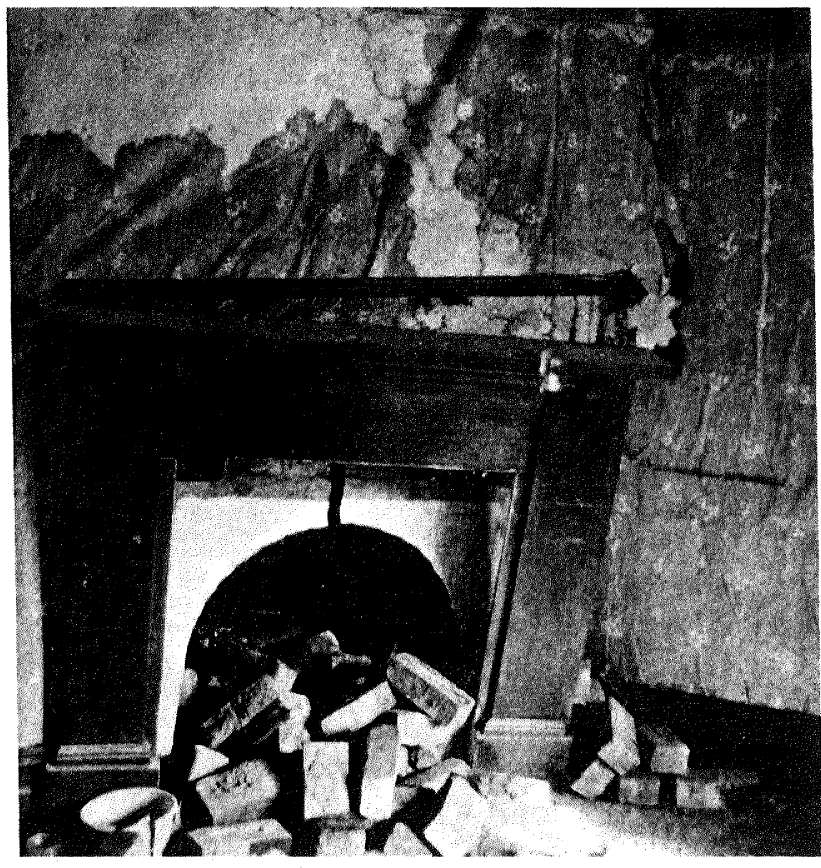

Fig. 16. Chimney disintegrated inside and bulged out walls 


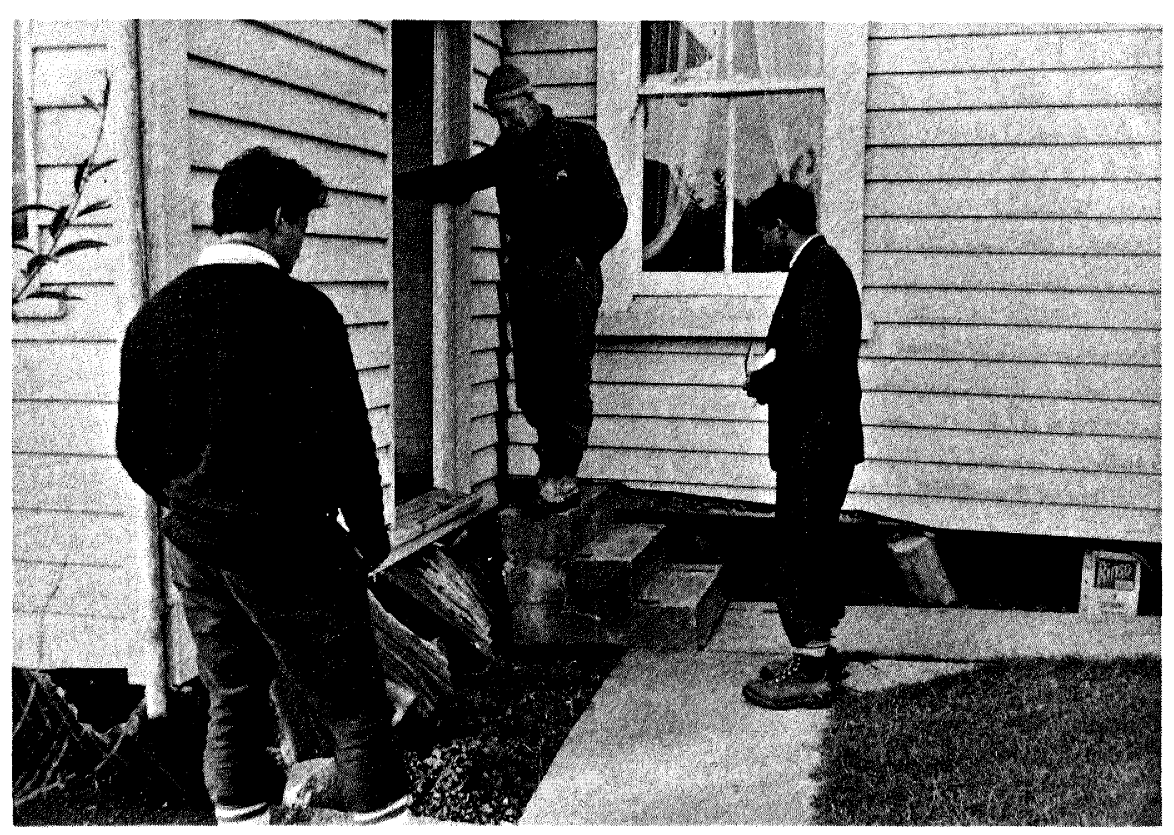

Fig. 17. Extent of movement from step top to door sill

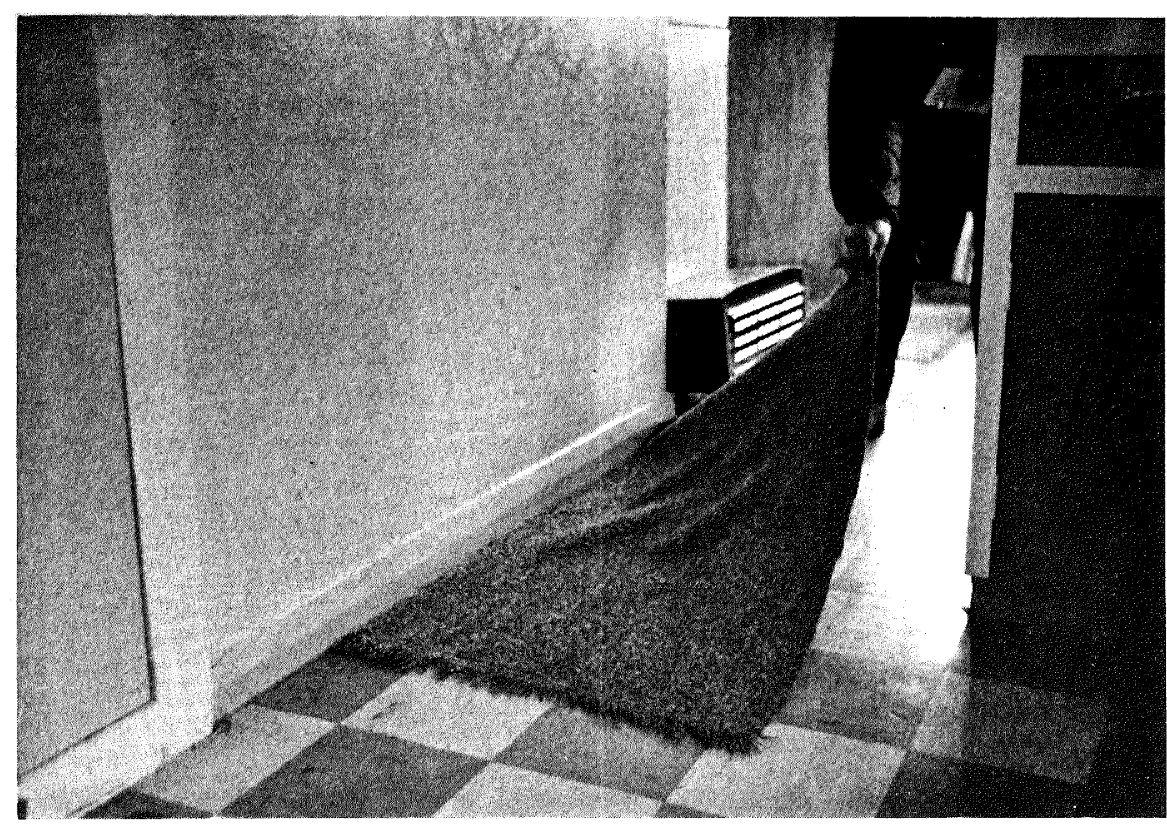

Fig. 18. Rug found jammed under skirting board (next house)

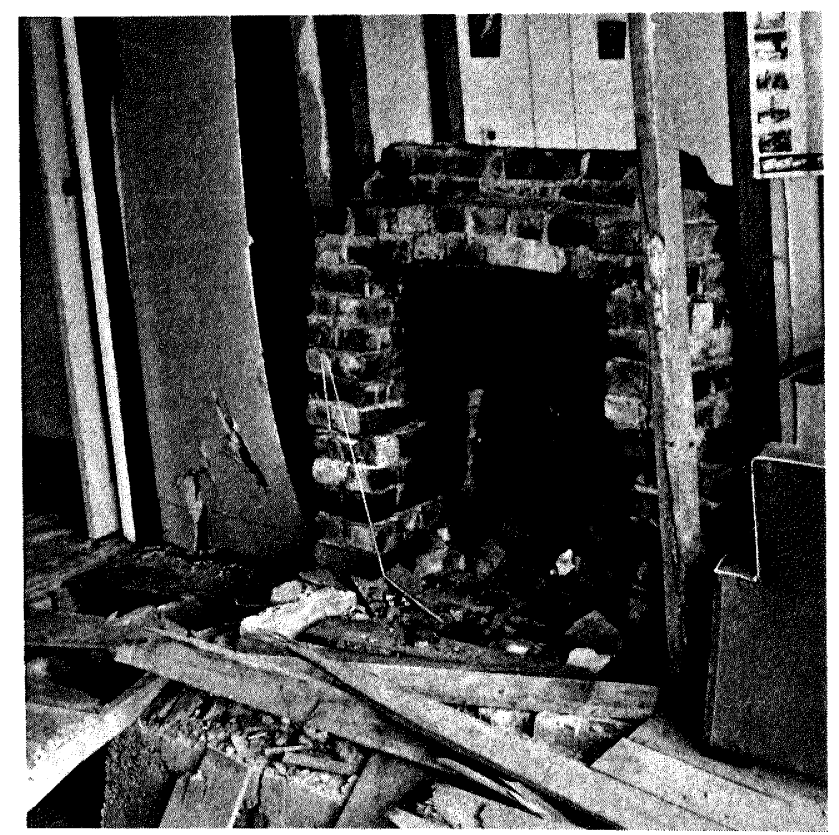

Fig. 19. Interior chimney collapse, dwelling of fig. 17

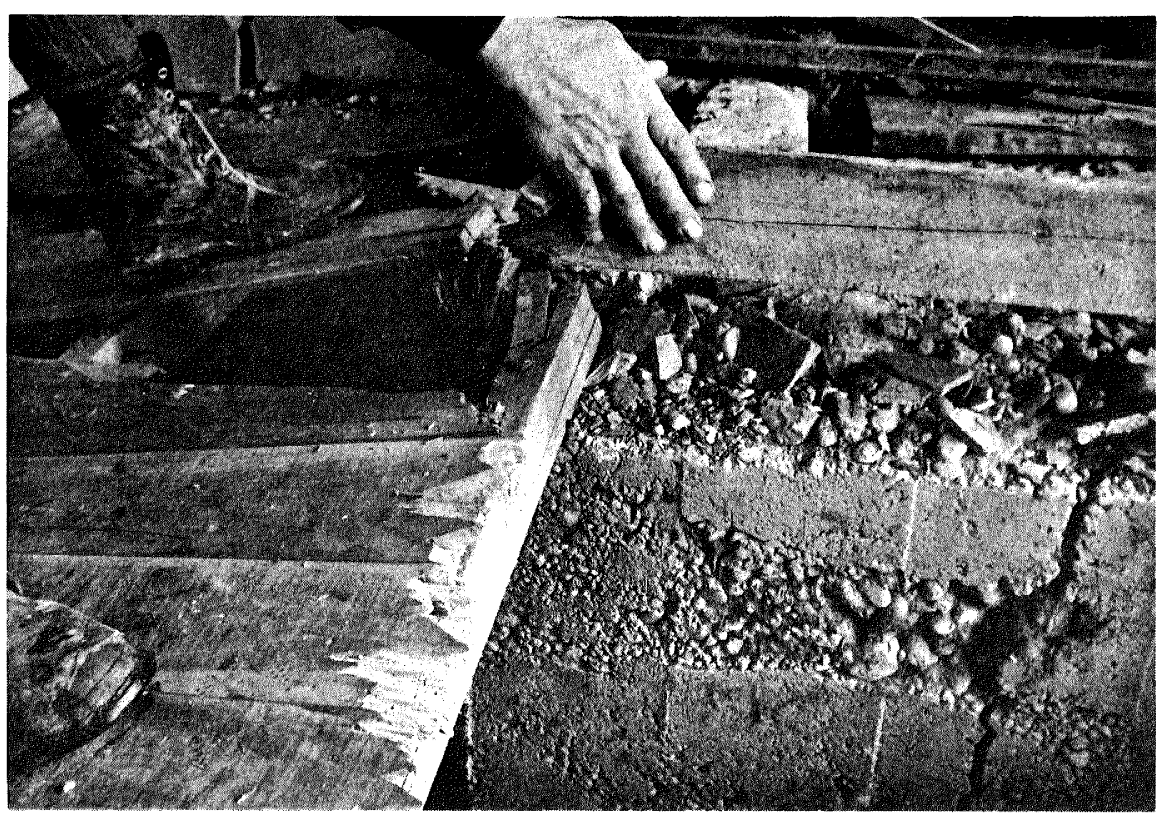

Fig. 20. Detail of fig. 19, flooring lifted on chimney base 


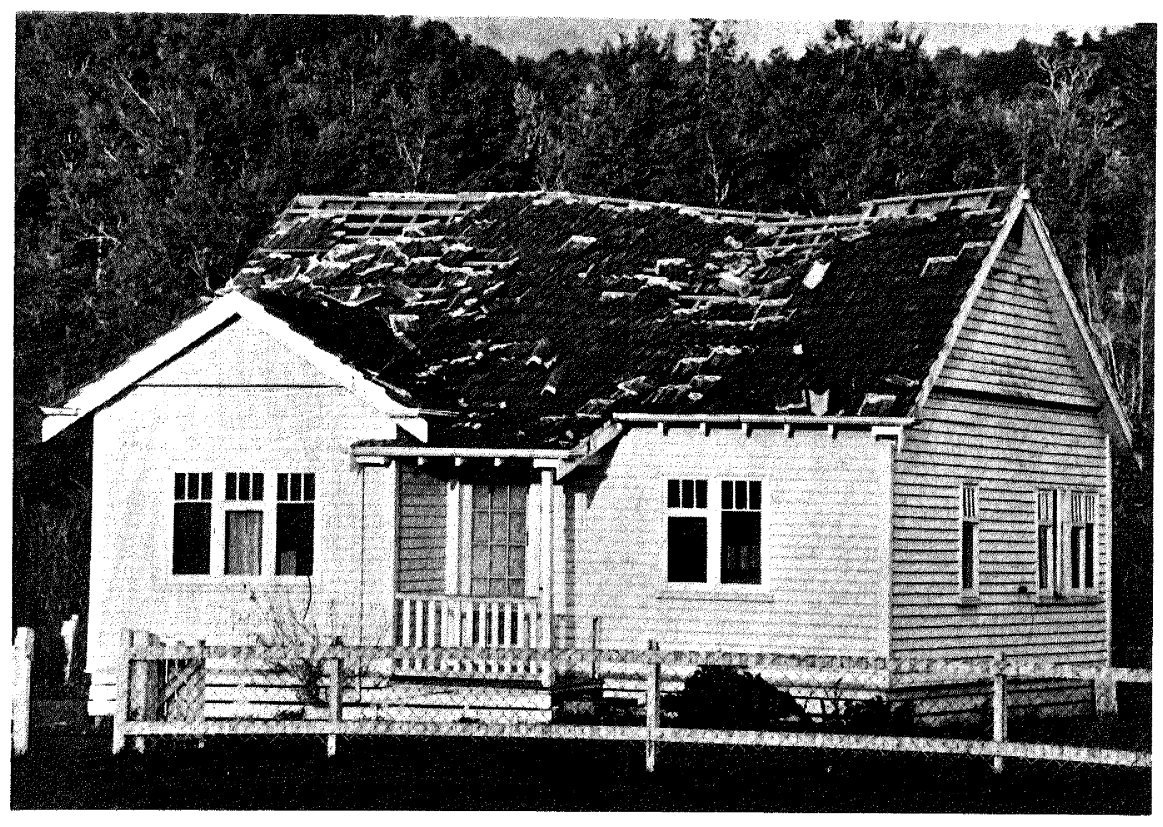

Fig. 21. Damaged tile roof of a dwelling in Inangahua Camp

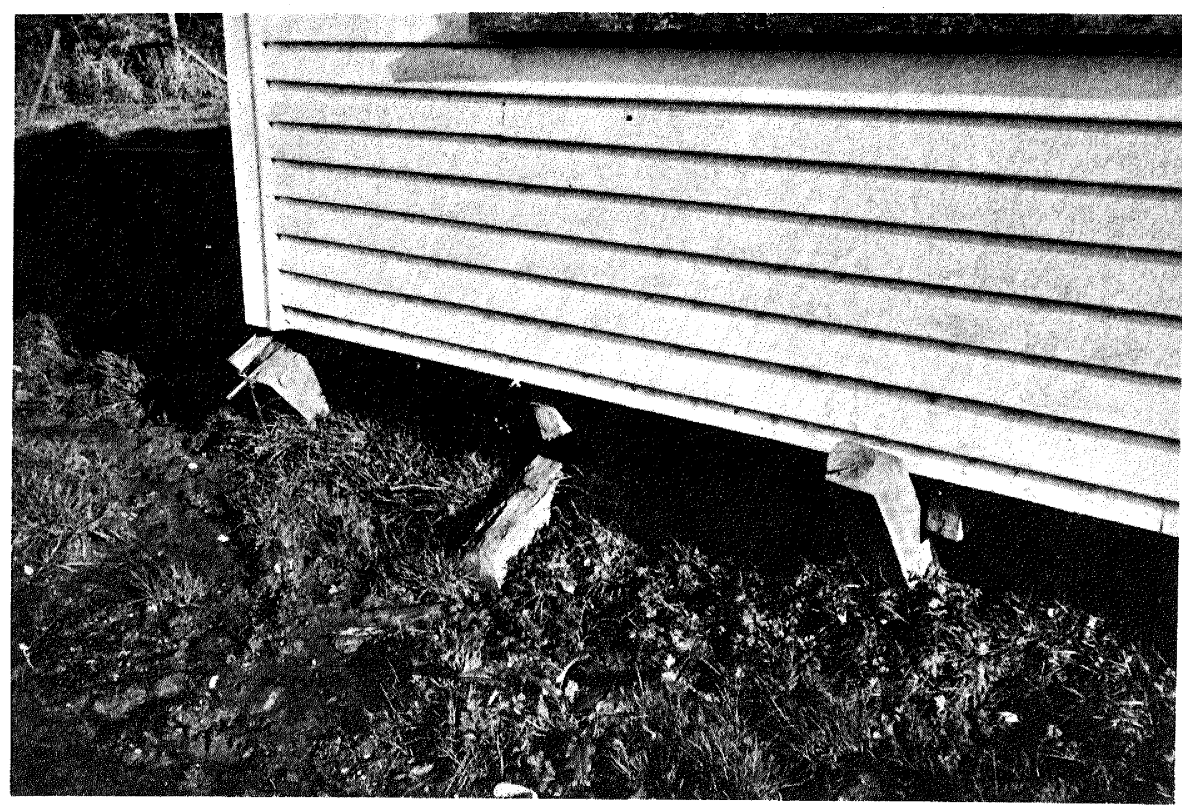

Fig. 22. Dwelling moved off, then evidently pushed piles

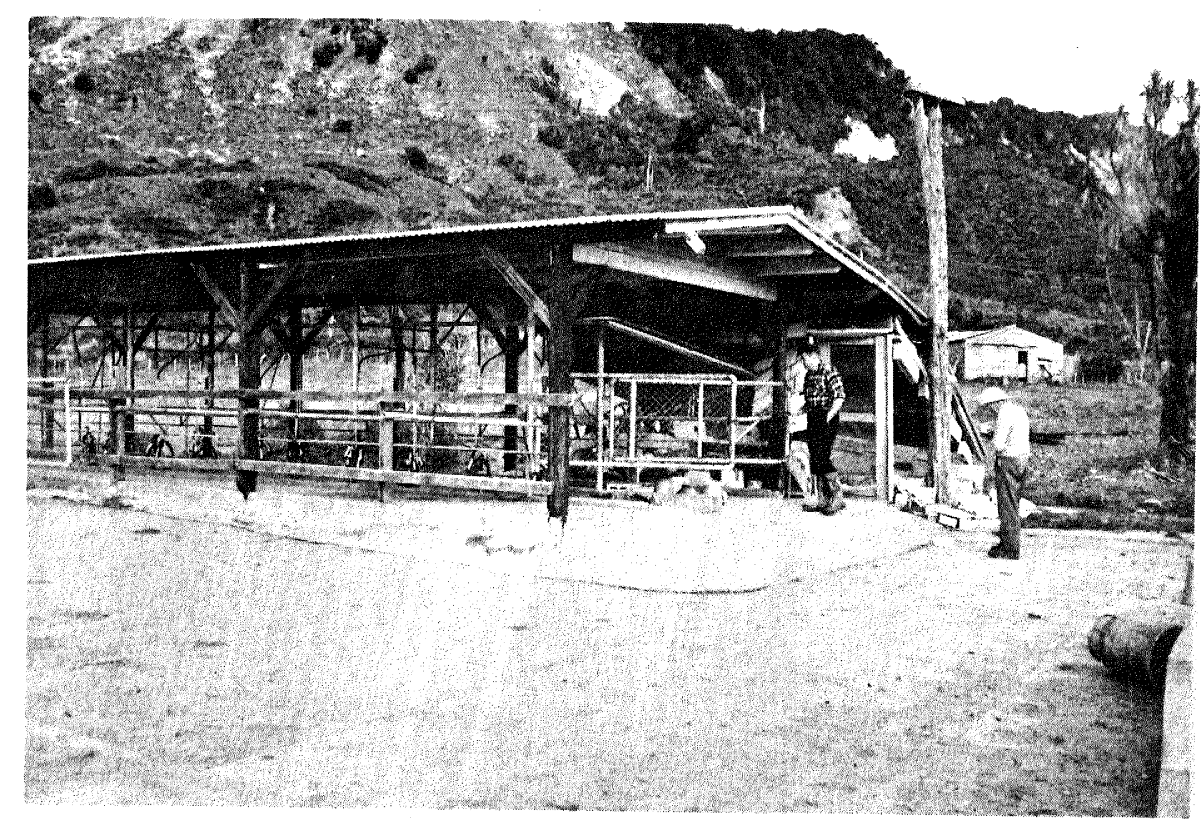

Fig. 23. Milking shed, mostly timber framed, $4 \mathrm{~km}$ w.n.w Camp

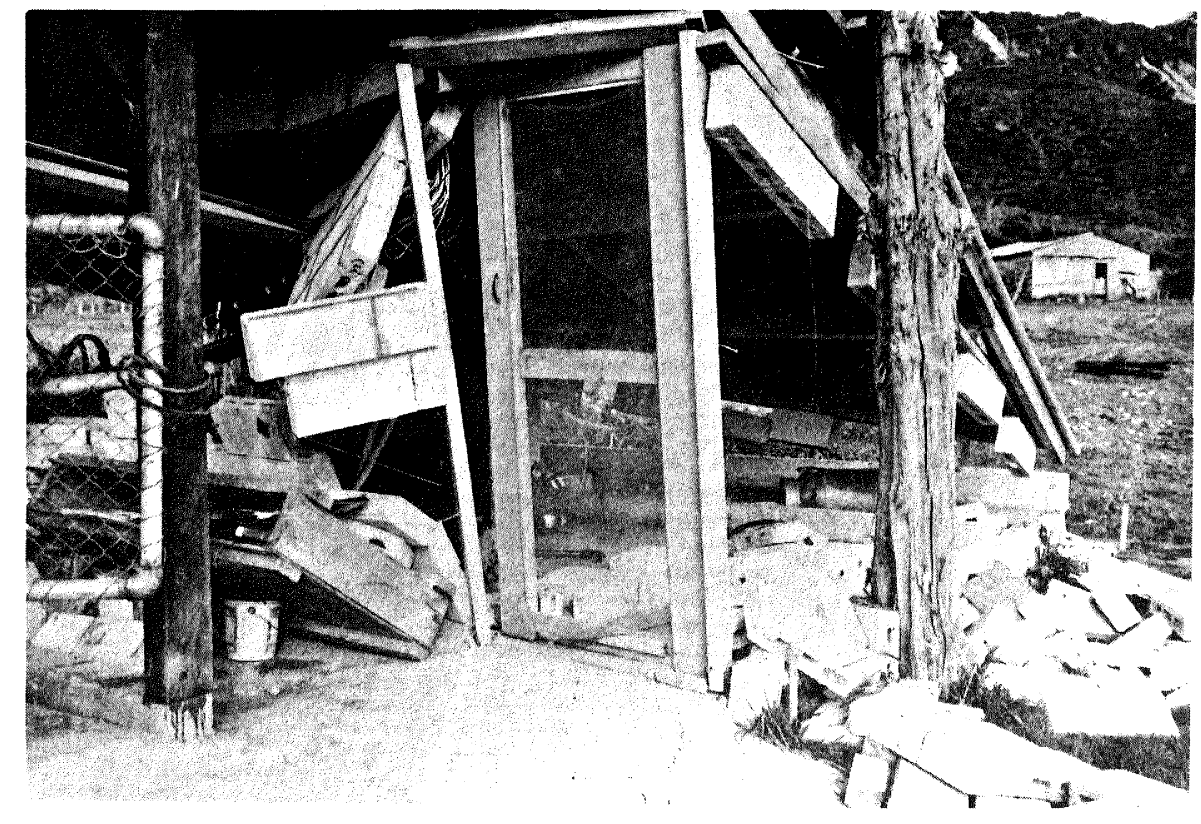

Fig. 24. Room of shed fig 23, weak unreinforced blockwork 


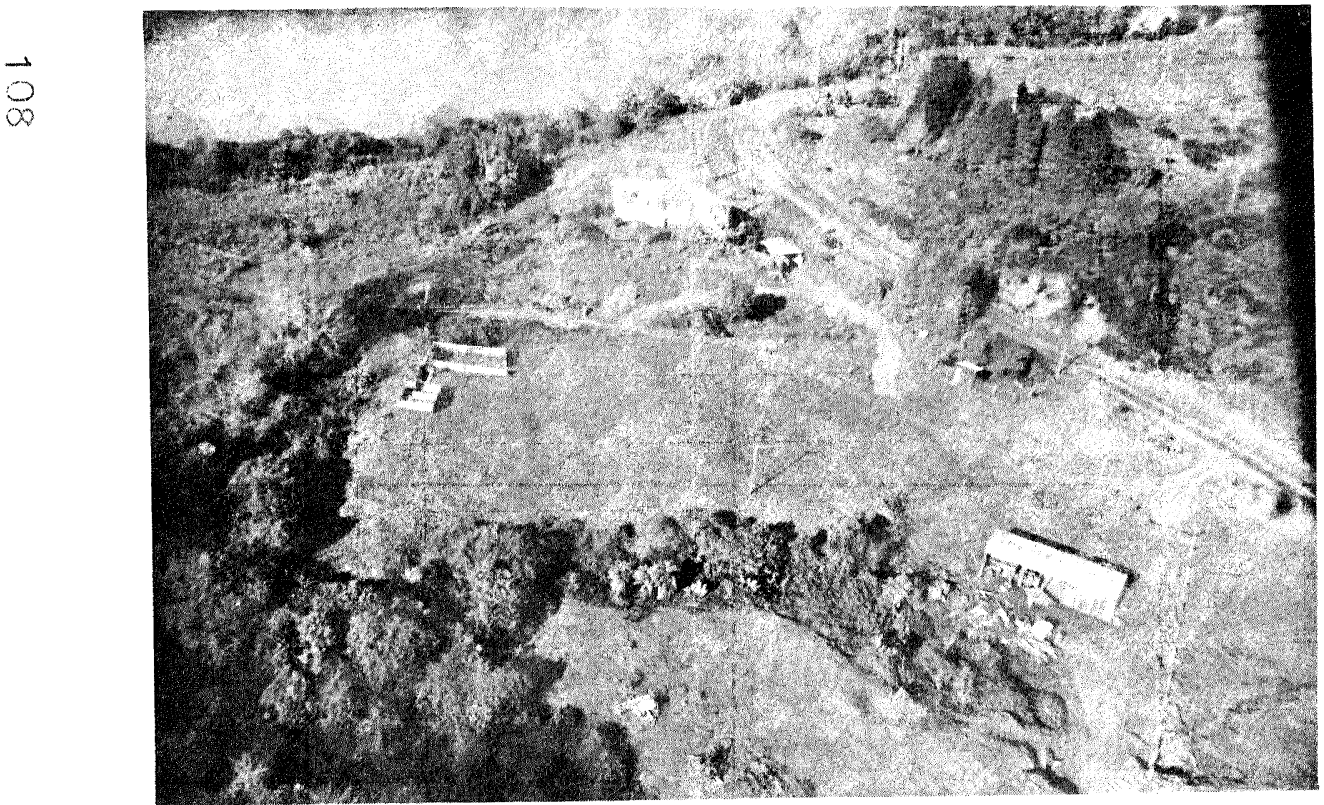

Fig 25. Dwelling on earth movement, $4 \mathrm{~km} \mathrm{w.n.w.} \mathrm{of} \mathrm{Ing'} \mathrm{Camp}$

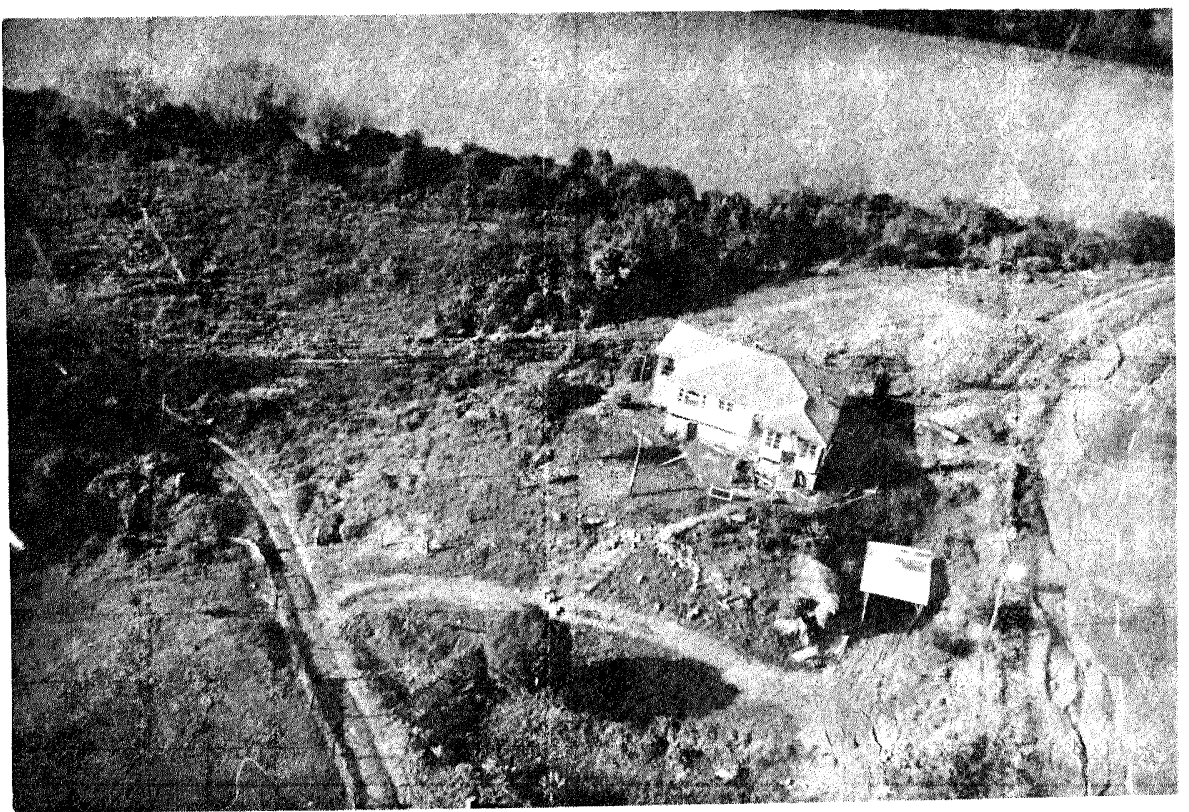

Fig. 26. Closer view. fig. 25

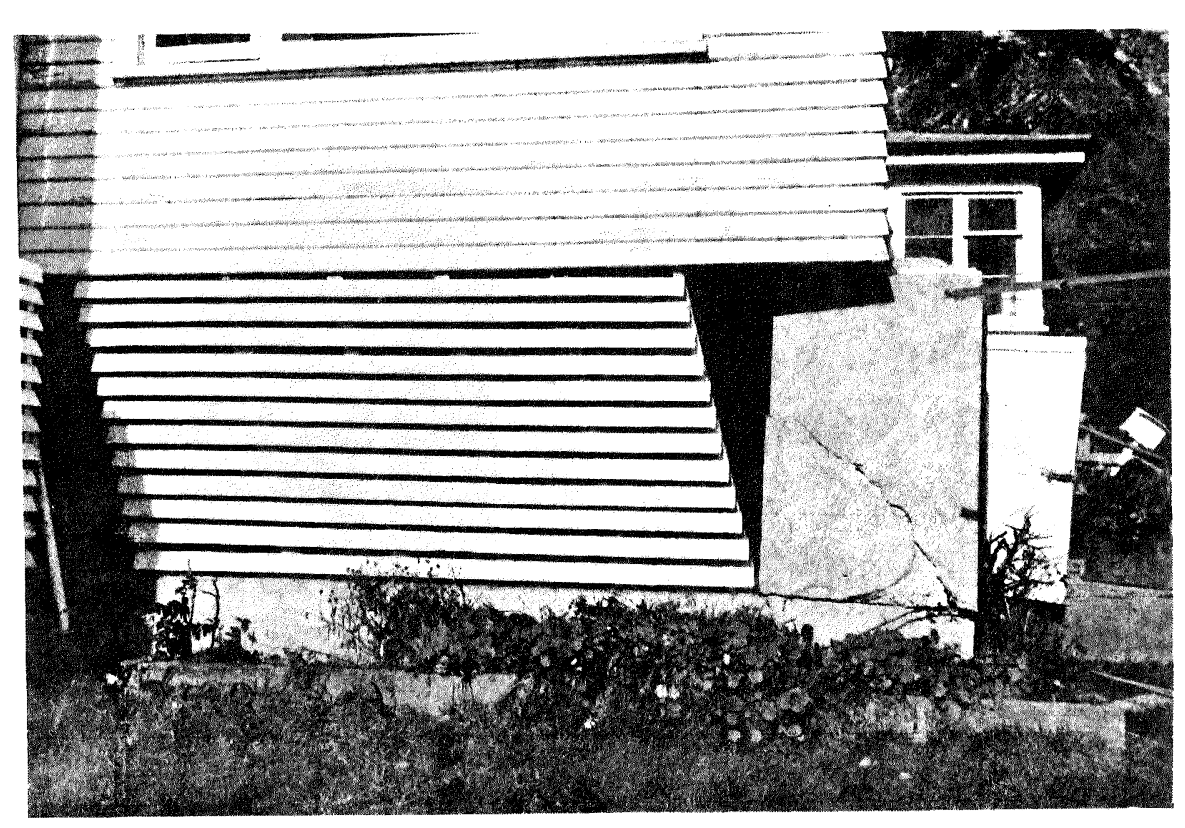

Fig. 27. Movement at foundation, fig 25, dwelling racked

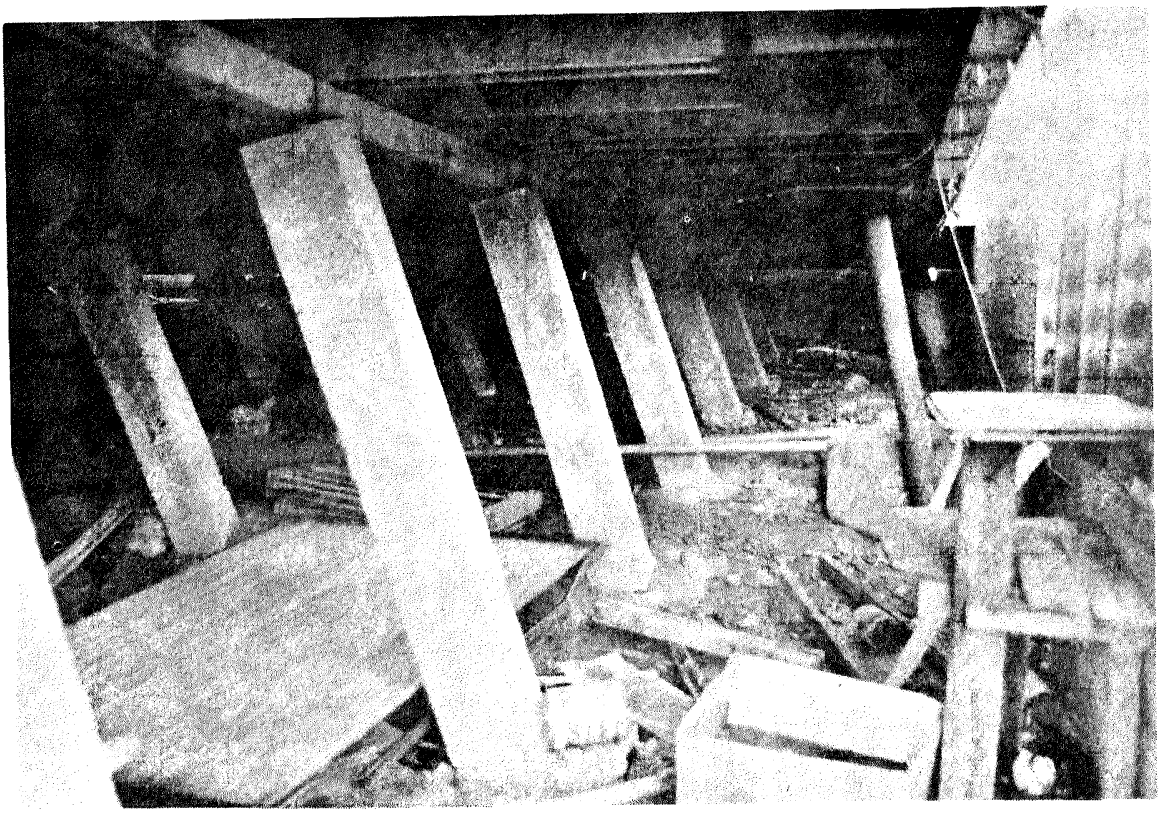

Fig. 28. Inclined piles under house, fig. 26 


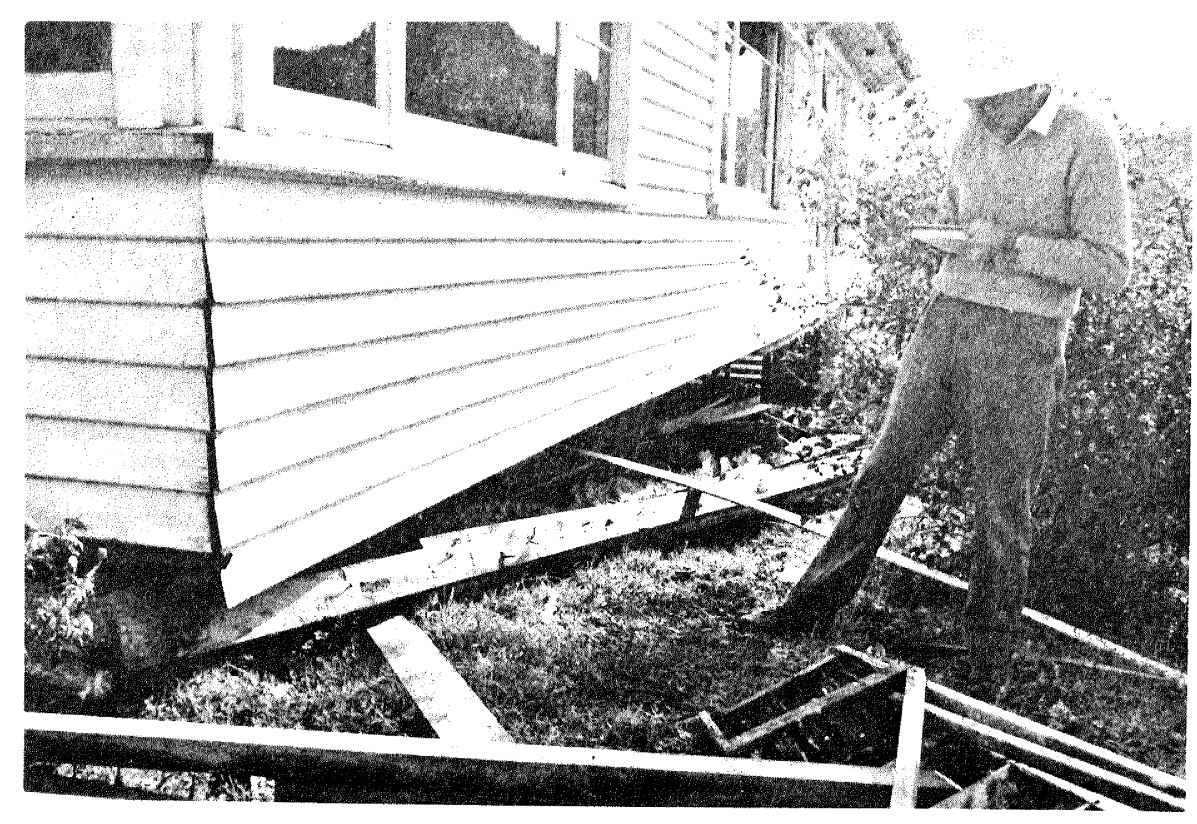

Fig. 29. Survey being made of damage and plan for repair

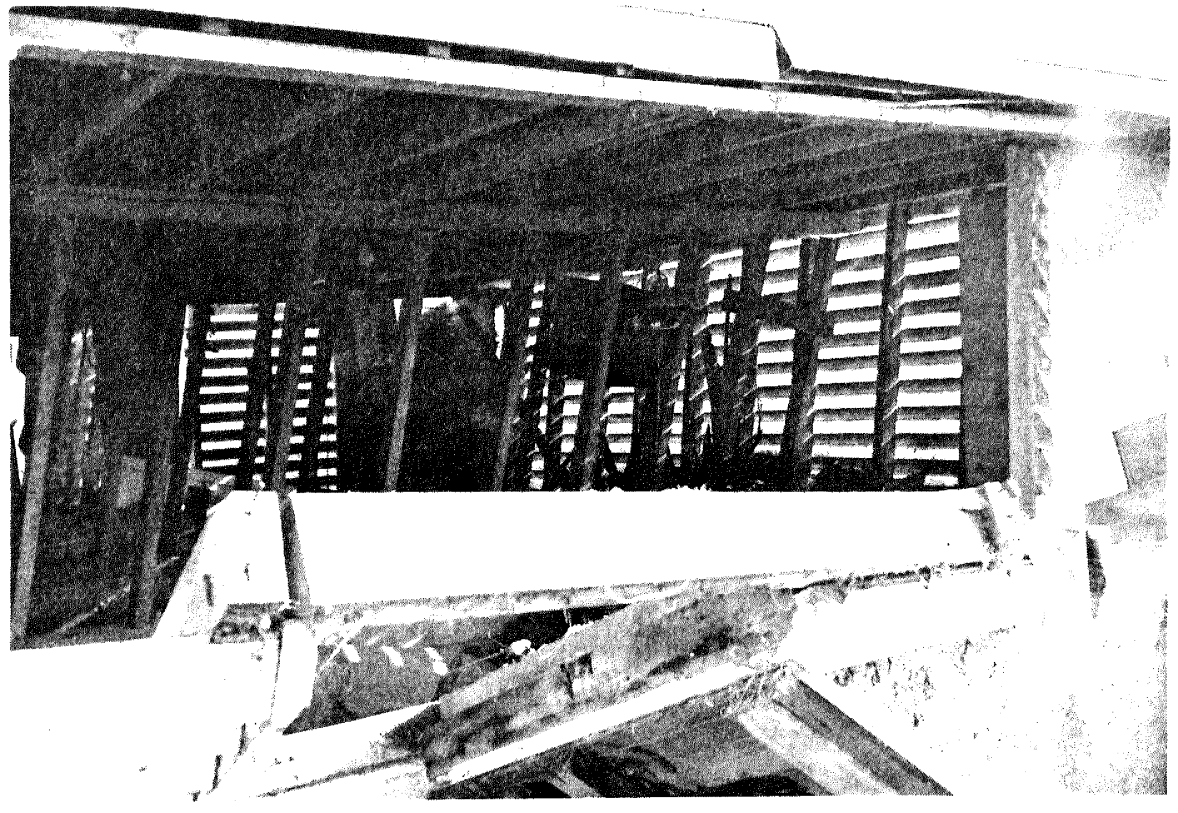

Fig. 30. Part of building perimeter foundation, folded out

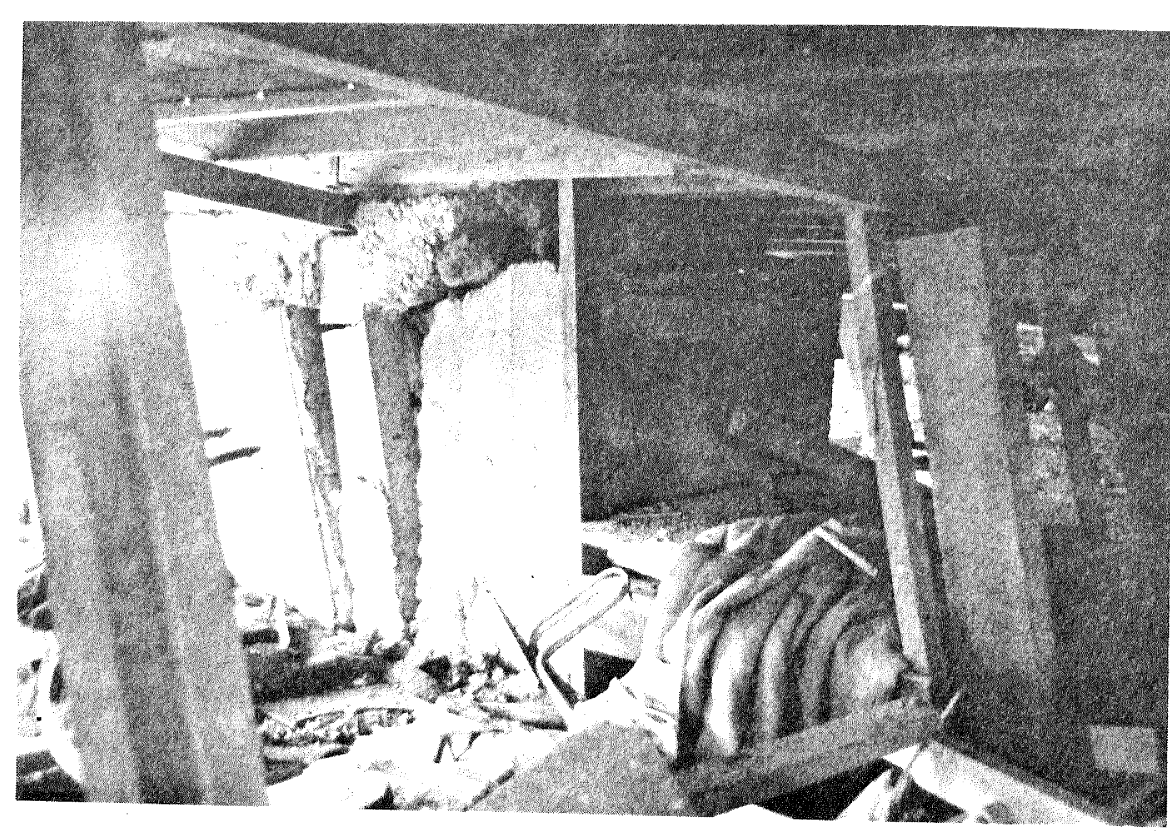

Fig. 31. Damage to chimney base fig. 25

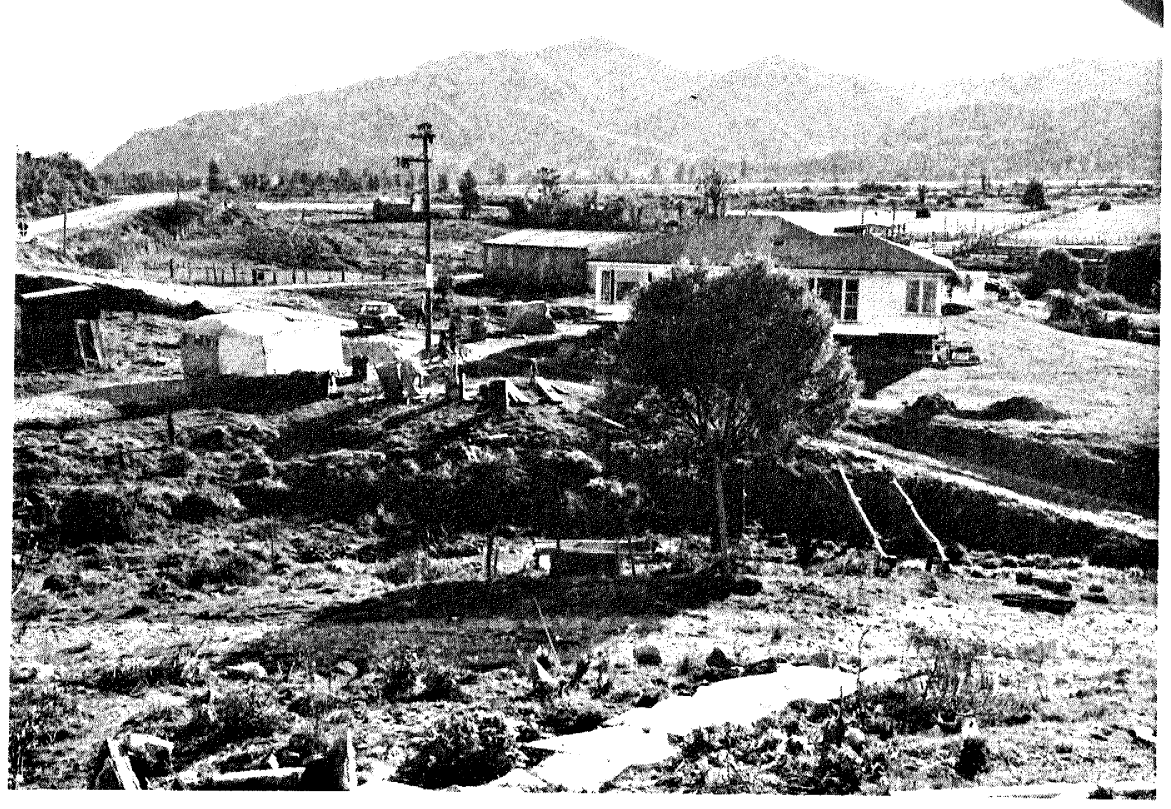

Fig. 32. House of fig. 25 after transport to new site below 
